\title{
Guidelines for Identification and Management of Plant Disease Problems: Part III. Managing Plant Diseases ${ }^{1}$
}

\author{
Aaron Palmateer, Ken Pernezny, Monica Elliott and Nikol Havranek ${ }^{2}$
}

\section{Introduction}

Now that you have learned how to diagnosis a plant disease, you can institute measures to manage it. Accurate disease diagnosis is an essential part of effective management. In our experience, failure to adequately manage a disease can often be traced back to a failure to correctly diagnose the problem. Once a disease is properly diagnosed, a reasonable disease management program can be developed with resources like books, fact sheets, the Web, and extension professionals.

Three elements are necessary for a disease to develop in a plant: a pathogen, a susceptible host, and an environment favorable for disease development. This is called the disease triangle (Fig. 1). All three parts of the triangle must be present for the disease to occur and at least one must be removed in order to manage the disease. Plant disease management can include plant crop resistance, cultural and physical methods, and chemical treatment. For most plant diseases, an integrated approach using more than one method is required. It is also important to note that some diseases are always fatal because there are currently no successful tools for their management.

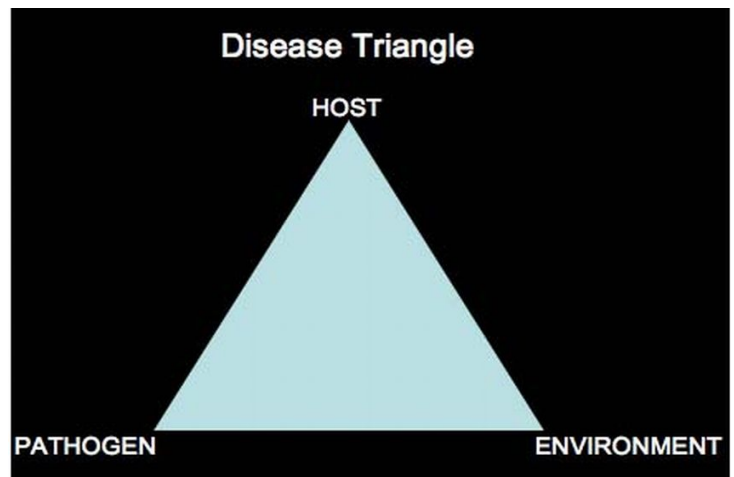

Figure 1. Disease Triangle.

\section{Plant Resistance}

Immunity is the rule in the plant kingdom; most plants are immune to most pathogens. Therefore, one does not have to worry that the black spot on roses will next appear on the garden tomatoes. For plant species that are susceptible to a particular plant pathogen, plant breeders strive to select varieties (cultivars) of the plant that have resistance to plant diseases. Many varieties of vegetable and ornamental

1. This document is PP 250, one of a series of the Plant Pathology Department, Florida Cooperative Extension Service, Institute of Food and Agricultural Sciences, University of Florida. Original publication date February 2008. Visit the EDIS Web Site at http://edis.ifas.ufl.edu.

2. Aaron Palmateer, assistant professor, Plant Diagnostic Clinic, Tropical Research and Education Center (REC)--Homestead, FL; Ken Pernezny, professor, Department of Plant Pathology, Everglades REC--Belle Glade, FL; Monica Elliott, professor, Department of Plant Pathology; Fort Lauderdale REC--Ft. Lauderdale, FL; Nikol Havranek, biological scientist, Everglades REC--Belle Glade, FL; Florida Cooperative Extension Service, Institute of Food and Agricultural Sciences, University of Florida, Gainesville FL 32611.

The Institute of Food and Agricultural Sciences (IFAS) is an Equal Opportunity Institution authorized to provide research, educational information and other services only to individuals and institutions that function with non-discrimination with respect to race, creed, color, religion, age, disability, sex, sexual orientation, marital status, national origin, political opinions or affiliations. U.S. Department of Agriculture, Cooperative Extension Service, University of Florida, IFAS, Florida A. \& M. University Cooperative Extension Program, and Boards of County Commissioners Cooperating. Larry Arrington, Dean 
plants with some level of resistance to the targeted plant pathogen can be found (Fig. 2). Merely choosing and planting these varieties will reduce disease problems. This is your first line of defense! There are also varieties that show more tolerance for specific diseases. In spite of the fact that these plants may seem to have as many symptoms as those that are not tolerant, somehow they still thrive and produce.
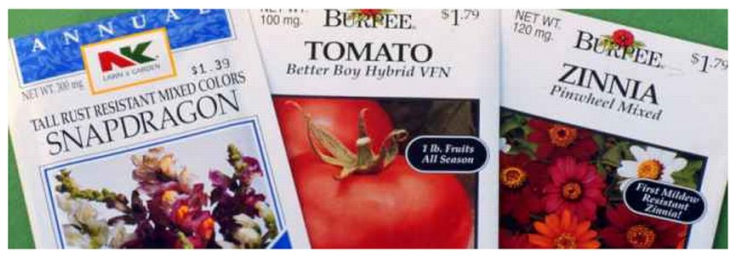

Figure 2. Seed packets.

Likewise, plants that are adapted for the local environment are more likely to remain disease free than non-adapted plants. This is often referred to as selecting the right plant for the site. A plant that prefers well-drained soils will not thrive in a site that is often water-logged. Plants that prefer low $\mathrm{pH}$ soil (acid soil) will not thrive in an alkaline soil (high $\mathrm{pH}$ soil). In these situations, the plants are weakened and may develop diseases they would otherwise resist. This is even true for "native" plants, which are not just native to Florida, but also to a particular environment (swamp, sand, rock, salt-spray, etc.).

\section{Cultural and Physical Methods}

Cultural and physical methods can also be used to help manage disease. These include sanitation, plant rotation, host eradication and improvement of the local environment surrounding the plant or plant grouping.

\section{Sanitation}

Sanitation involves removal of diseased plants and plant parts, and buying disease-free plants and cleaning tools. All of these actions will help to prevent further spread of the pathogen. The diseased plant material should be removed from the area, and can be buried in a properly constructed compost pile or, where available, placed in garbage that will be incinerated. When buying plants for home use, it is very important to make sure that they are disease free. This is especially important for bacterial diseases. It is not uncommon to find infected seedlings in many of the retail nurseries (Fig. 3). If you suspect a plant is infected after you arrive home with it, quarantine the plant for a week by leaving it in a pot away from other plants and monitoring it closely.

Some pathogens can be carried from plant to plant on hands and tools, especially pruning tools. It is important to disinfect hands and tools that are used with plants. For tools, a 20-30\% solution of household bleach or pine oil product in water makes a good disinfectant. Rubbing alcohol from the drug store will also work, as will trisodium phosphate available from orchid supply stores and web sites. Soak the tool at least 5 minutes, and then rinse with clean water or allow to air dry. Washing your hands with soap under running water is all that is necessary to clean your hands after working with diseased plant material. In general, plant pathogens are not harmful to humans.

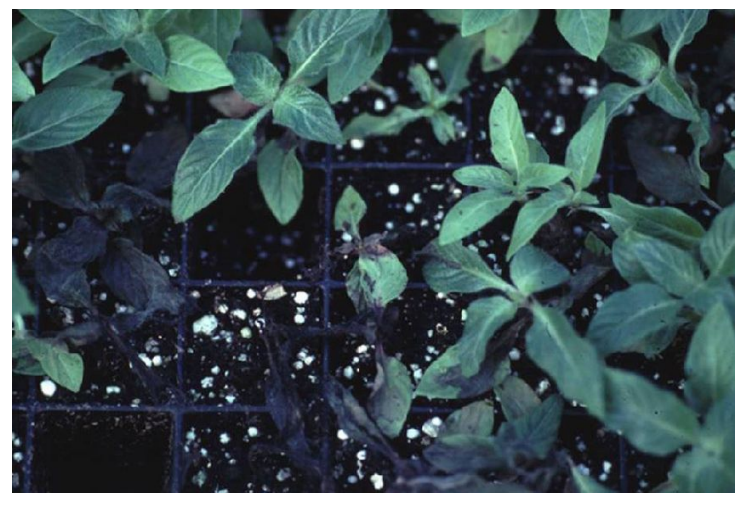

Figure 3. Diseased seedlings in flat.

\section{Rotation}

As stated above, most plants are not susceptible to most pathogens. This means plant pathogens are fairly host specific. In a vegetable garden or annual ornamental bed, rotating plant species from season to season will decrease the population of the pathogen because one aspect of the disease triangle, the host, has been removed. 


\section{Host Eradication}

Sometimes the best approach is to thoroughly remove all plants that might be possible pathogen hosts. For instance, the weeds surrounding a garden or yard may be host plants and should be eradicated. Another example can be found among certain plant species, especially trees and palms, for which there are no known resistant varieties to a particular disease and no known controls. If that plant species dies from a particular disease, the best recommendation is to avoid planting the same species in its former location.

\section{Water Management}

Most fungi and bacteria that cause leaf diseases require free water (rain, dew, irrigation water) or very high humidity (>90\%) in order to infect the host tissue and initiate disease. Therefore, water management is an important disease management tool. Hand watering is preferable because it can be restricted to the soil around the roots of plants and not the foliage. It is also important to water after dew has formed, but early enough to allow for fairly rapid drying of the irrigation water. The early morning hours are a good choice for watering. Water requirements vary for each plant species, and each season. This means your watering schedule will change throughout the year. Often, the "dry" season in Florida coincides with the coolest time of year, when most ornamental plants are not actively growing and do not require as much water. Reduce the need to irrigate the entire landscape by grouping plants that have the same water requirements; put the plants that need the most water in one place, and those that are drought tolerant in another place, being sure to schedule your irrigation system or hand watering accordingly.

\section{Other Cultural Methods}

While water management is one way to improve the localized environment to minimize disease development, other cultural methods should be used in your garden and landscape. Knowing the proper time to plant and the proper depth to place the seeds, seedlings, plant or tree is important. Poorly drained soil should be avoided. If possible, even in home gardens, one should plant on raised beds to ensure good drainage. For vegetable and annual ornamental gardens, fertilizer should only be applied after the soil has been tested to determine which nutrients are deficient. For perennial ornamental plants, palms and fruit trees, use appropriate slow-release fertilizers and monitor for nutrient deficiencies based on the symptoms and leaf tissue analysis.

Knowing the site's disease history can help with planting decisions. Wider plant spacing provides for good air movement and promotes more rapid drying after rains or irrigation. Plant injuries provide access for pathogens, so care should be taken with plants and plant parts during production and distribution. Plants will do better in looser soil. Mulching can also help keep weeds down, retain soil moisture and prevent foliage and fruit from touching plant pathogen-infested soil.

\section{Chemical Treatment}

Chemical application may still be necessary despite efforts at curbing disease through plant resistance and cultural and physical methods. However, chemicals should only be used as part of an Integrated Plant Disease Management program, and should not be the first or exclusive choice for plant disease management. Moreover, chemical application does not eliminate the disease symptoms present at the time of the application, but, rather, protects uninfected plant tissue. Chemicals are primarily used to prevent further spread of disease both on individual plants and between adjacent plants. For example, the leaf spot present on a leaf when the fungicide is applied will still be there after treatment. The spot does not heal, but will remain until the leaf naturally dies or is pruned. Hopefully, however, no further spots will develop on that plant or nearby healthy plants.

While many fungal diseases have chemical control options (fungicides), viral diseases cannot be directly controlled with chemicals, although insecticides or miticides may be useful in limiting spread of the vector. Bacterial diseases also can only be treated with very few chemical control methods. Chemical treatment is not an option for some diseases. 
Chemical methods include seed treatment, foliar sprays or dusts, and soil or container drenches. Only apply the amounts specified on the labels and use the proper pesticide for the plant and the particular problem. The information on the chemical label is mandated by law, so make sure the chemical is labeled for your intended location and use. For example: Some fungicides may be used on ornamental plants in the landscape but not on turfgrass. Some fungicides may be used on an ornamental plant growing in a greenhouse but not in a landscape. Some fungicides may be used in the landscape only if applied by a licensed pesticide applicator. Correct timing of application is also important; one should follow extension guidelines in planning an IPM program. No chemical recommendations should be made to the public without first consulting with the Master Gardener coordinator.

\section{Web Resources}

-Homeowners Guide to Fungicides for Lawn and Landscape Disease Management

http://edis.ifas.ufl.edu/PP154. 